\title{
Pengaruh Pertumbuhan Ekonomi, Upah Minimum, Tingkat Pengangguran Terbuka Dan Pendidikan Terhadap Jumlah Penduduk Miskin
}

\author{
Hapsari Wiji Utami ${ }^{\mathrm{a}}$ \\ Siti Umajah Masjkuri ${ }^{\mathrm{b}}$ \\ ${ }^{a}$ Sekolah Pascasarjana Universitas Airlangga ${ }^{b}$ Fakultas Ekonomi dan Bisnis Universitas Airlangga \\ Email: utamihapsariwiji@gmail.com ${ }^{\text {a }}$; sitimasjkuri@gmail.com $^{\text {b }}$
}

ARTICLE HISTORY

Received:

9 July 2018

Revised

15 August 2018

Accepted:

1 September 2018

Online available:

10 November 2018

Keywords (Calibri 10):

Number of Poor

Population,

Economic Growth, Minimum Wage, Open Unemployment

Rate and Education

Kata Kunci:

Jumlah Penduduk

Miskin,

Pertumbuhan

Ekonomi,

Upah Minimum,

Tingkat Pengangguran

Terbuka dan

Pendidikan

\section{ABSTRACT}

Introduction: This study examines the effects of economic growth, minimum wages, open unemployment and education (average length of school) on the number of poor people in districts / cities in East Java Province. The purpose of this research is expected to be able to analyze how and how much influence economic growth, minimum wages, open unemployment and education (average length of schooling) on the number of poor people in East Java, so that later it is expected to be used as one of the bases in determining policy in overcoming the problem of poverty in East Java.

Methods: The data used in this study are secondary data obtained from the Central Statistics Agency (BPS) and the Manpower Office as supporters. The analysis method used in this research is panel data regression analysis method with the FEM method with the help of Eviews 6 software.

Results: The results of this study indicate that the Economic Growth variable has a negative but insignificant effect on the level of the number of poor people, the Minimum Wage variable has a significant negative effect on the number of poor people, the Open Unemployment Rate variable has a significant negative effect on the number of poor people and the Education variable (long average schools have a significant negative effect on the number of poor people in East Java.

Conclusion and suggestion: The provincial government of East Java should increase the total production of goods and services produced in all districts / cities in East Java, taking into account the provincial minimum wage so that it can reduce the number of poor people in all districts / cities in East Java and further stimulate the formal sector. 


\section{ABSTRAK}

Kemiskinan merupakan masalah yang menyangkut banyak aspek karena berkaitan dengan pendapatan yang rendah, buta huruf, derajat kesehatan yang rendah dan ketidaksamaan derajat antar jenis kelamin serta buruknya lingkungan hidup (Word Bank, 2010). Mengatasi masalah kemiskinan tidak dapat dilakukan secara terpisah dari masalah-masalah pertumbuhan ekonomi, upah minimum, tingkat pengangguran terbuka dan pendidikan juga masalah-masalah lain yang secara eksplisit berkaitan erat dengan masalah kemiskinan.

Studi ini meneliti tentang pengaruh pertumbuhan ekonomi, upah minimum, tingkat pengangguran terbuka dan pendidikan (rata-rata lama sekolah) terhadap jumlah penduduk miskin kab/kota di Provinsi Jawa Timur. Tujuan penelitian ini diharapkan dapat menganalisis bagaimana dan seberapa besar pengaruh pertumbuhan ekonomi, upah minimum, tingkat pengangguran terbuka dan pendidikan (rata-rata lama sekolah) terhadap jumlah penduduk miskin di Jawa Timur, sehingga nantinya diharapkan dapat digunakan sebagai salah satu dasar dalam penentuan kebijakan dalam mengatasi masalah kemiskinan di Jawa Timur. Data yang digunakan dalam penelitian ini adalah data sekunder yang diperoleh dari Badan Pusat Statistik (BPS) serta Disnaker sebagai pendukung. Metode analisis yang digunakan dalam penelitian ini adalah metode analisis regresi data panel dengan metode FEM dengan bantuan software Eviews 6 .

Hasil dari penelitian ini menunjukkan bahwa variabel Pertumbuhan Ekonomi berpengaruh negatif tetapi tidak signifikan terhadap tingkat jumlah penduduk miskin, variabel Upah Minimum berpengaruh negatif signifikan terhadap jumlah penduduk miskin, variabel Tingkat Pengangguran Terbuka berpengaruh negatif signifikan terhadap jumlah penduduk miskin dan variabel Pendidikan (rata-rata lama sekolah berpengaruh negatif signifikan terhadap jumlah penduduk miskin di Jawa Timur.

\section{INTRODUCTION}

Salah satu tujuan pembangunan nasional adalah meningkatkan kinerja perekonomian agar mampu menciptakan lapangan kerja dan menata kehidupan yang layak bagi seluruh rakyat yang pada gilirannya akan mewujudkan kesejahteraan penduduk Indonesia. Salah satu sasaran pembangunan nasional adalah menurunkan tingkat kemiskinan.

Menurut Todaro dan Smith (2006), kemiskinan yang terjadi di negara negara berkembang akibat dari interaksi antara 6 karakteristik berikut:

1. Tingkat pendapatan nasional negara-negara berkembang terbilang rendah dan laju pertumbuhan ekonominya tergolong lambat.

2. Pendapatan perkapita negara-negara berkembang juga masih rendah dan pertumbuhannya sangat lambat, bahkan ada beberapa yang mengalami stagnasi.

3. Distribusi pendapatan sangat timpang atau sangat tidak merata.

Published by University of Airlangga.

This is an open access article under the CC BY license (https://creativecommons.org/licenses/by-sa/4.0/) 
4. Mayoritas penduduk di negara-negara berkembang harus hidup di bawah tekanan kemiskinan absolut.

5. Fasilitas dan pelayanan kesehatan buruk dan sangat terbatas, kekurangan gizi dan banyaknya wabah penyakit sehingga tingkat kematian bayi di negara-negara berkembang sepuluh kali lebih tinggi dibandingkan dengan yang ada di negara maju.

Proses pembangunan memerlukan pendapatan nasional yang tinggi dan pertumbuhan ekonomi yang cepat. Di banyak negara syarat utama bagi terciptanya penurunan kemiskinan yang tetap adalah pertumbuhan ekonomi. Pertumbuhan ekonomi memang tidak cukup untuk mengentaskan kemiskinan tetapi biasanya pertumbuhan ekonomi merupakan sesuatu yang dibutuhkan, walaupun begitu pertumbuhan ekonomi yang bagus pun menjadi tidak akan berarti bagi penurunan masyarakat miskin jika tidak diiringi dengan pemerataan pendapatan (Wongdesmiwati, 2009).

Jawa Timur adalah provinsi yang terletak di ujung timur Pulau Jawa, dimana jumlah penduduk provinsi ini menempati urutan kedua setelah provinsi Jawa Barat. Selain itu, ibu kota provinsi Jawa Timur, Surabaya, dinobatkan sebagai kota metropolitan terbesar kedua setelah Jakarta. Jawa Timur juga merupakan salah satu provinsi dengan tingkat pertumbuhan ekonomi yang paling tinggi di Indonesia. Pada tahun 2013 tingkat pertumbuhan ekonomi Jawa Timur mencapai 6,55\%. Selain itu wilayah Jawa Timur secara ekonomi menyumbang lebih kurang 15\% dari perekonomian nasional. Besarnya kegiatan ekonomi di Jawa Timur ini disebabkan tingginya arus perdagangan barang dan jasa yang memiliki peran penting dalam perekonomian Jawa Timur.

Dalam pembangunan ekonomi ada juga saat-saat kegagalan pemerintah membangun ekonomi, kegagalan pertumbuhan ekonomi meretas kemiskinan cenderung disebabkan oleh gagalnya pemerintah dalam mengelola laju pertumbuhan ekonomi. Kegagalan pemerintah dalam mengatur sistem pemberian upah padahal upah adalah sumber penghasilan, bila sumber penghasilan turun atau tetap maka kesejahteraan juga turun atau tetap dan itu juga pasti mempengaruhi tingkat kemiskinan.

Gagasan upah minimum yang sudah dimulai dan dikembangkan sejak awal tahun 1970-an bertujuan untuk mengusahakan agar dalam jangka panjang, besarnya upah minimum paling sedikit dapat memenuhi kebutuhan hidup minimum (KHM). Hal ini diharapkan dapat menjamin tenaga kerja untuk memenuhi kebutuhan hidup beserta keluarga dan sekaligus dapat mendorong peningkatan produktivitas kerja dan kesejahteraan buruh (Sumarsono, 2003).

Dalam sudut pandang makro ekonomi, pengangguran yang tinggi merupakan masalah. Salah satu gambaran dampak dari tingginya tingkat pengangguran adalah akan banyaknya sumber daya yang terbuang percuma dan pendapatan masyarakat berkurang (Samuelson dan Nordhaus, 2010). Pengangguran terbuka adalah pengangguran yang 
tercipta sebagai akibat pertambahan lapangan kerja yang lebih rendah dari pertumbuhan tenaga kerja. Akibatnya dalam perekonomian semakin banyak jumlah tenaga kerja yang tidak memperoleh pekerjaan.

Menurut Todaro (2006) teori pertumbuhan baru menekankan pentingnya peranan pemerintah terutama dalam meningkatkan pembangunan modal manusia (human capital) dan mendorong penelitian dan pengembangan untuk meningkatkan produktivitas manusia. Kenyataannya dapat dilihat dengan melakukan investasi pendidikan akan mampu meningkatkan kualitas sumber daya manusia yang diperlihatkan dengan meningkatnya pengetahuan dan keterampilan seseorang. Semakin tinggi tingkat pendidikan seseorang, maka pengetahuan dan keahlian juga akan meningkat sehingga akan mendorong peningkatan produktivitas kerjanya.

Dalam rangka mempercepat upaya pengentasan masyarakat miskin, pemerintah provinsi dan pemerintah kabupaten/kota perlu menyusun strategi, kebijakan dan program penanggulangan kemiskinan daerah sesuai dengan karakteristik dan sumber daya masing-masing. MDG's (Millenium Development Goals) muncul sebagai akibat kemiskinan dan kelaparan yang masih terus melanda di negara-negara berkembang di dunia menyebabkan FAO (Organisasi Pangan dan Pertanian PBB) prihatin dan kemudian menggagas program MDG's yang harus mencapai tujuannya pada tahun 2015, terutama dalam hal pengurangan kemiskinan menjadi setengahnya pada tahun 2015. Hingga dibutuhkan suatu upaya melalui Pemerintah Daerah untuk melakukan suatu inisisasi dalam bentuk program-program pengentasan kemiskinan sebagai suatu bentuk kontribusi dalam meminimalisir angka kemiskinan Nasional (Husna dan Hermawan, 2010).

Menurut Masri Singarimbun (1976), kemiskinan merupakan permasalahan yang multidimensi tidak dapat dipandang dari satu sisi saja dikarenakan kemiskinan memiliki permasalahan yang saling kait mengkait, namun dalam penelitian ini variabel yang dipilih adalah variabel pertumbuhan ekonomi, upah minimum, tingkat pengangguran terbuka dan pendidikan, oleh karena itu hasil dari penelitian ini tidak dapat di-generalisir secara umum.

\section{LITERATURE REVIEW}

\section{The Traditional Society}

Beberapa teori yang membahas mengenai tingkat kemiskinan pada penelitian ini meliputi:

1. Fenomena Keterbelakangan oleh Todaro

Published by University of Airlangga.

This is an open access article under the CC BY license (https://creativecommons.org/licenses/by-sa/4.0/) 
Todaro (2006) menyatakan keterbelakangan penduduk negara berkembang terutama disebabkan karena tingkat pertumbuhan penduduk yang tinggi dan penyerapan tenaga kerja yang rendah, menyebabkan produktivitasnya rendah sehingga pendapatan rendah, hal ini mengakibatkan rendahnya standar kualitas hidup atau rendahnya tingkat hidup.

2. Teori Lingkaran Kemiskinan (Vicious Circle Of Poverty)

Teori lingkaran kemiskinan (vicious circle of poverty) oleh Ragnar Nurkse (1953) (dalam Jhingan, 2004) menjelaskan bahwa lingkaran kemiskinan adalah suatu lingkaran rangkaian yang saling mempengaruhi satu sama lain sedemikian rupa, sehingga menimbulkan suatu keadaan dimana negara akan tetap miskin dan akan banyak mengalami kesukaran untuk mencapai tingkat pembangunan yang lebih baik.

3. Teori T.R.Malthus

Menurut teori Malthus (dalam Todaro, 2006) yang menyatakan bahwa: pertambahan jumlah penduduk adalah seperti deret ukur $(1,2,4,8,16, \ldots)$, sedangkan pertambahan jumlah produksi makanan adalah bagaikan deret hitung $(1,2,3,4,5, \ldots)$. Hal ini tentu saja akan sangat mengkhawatirkan di masa depan dimana kita akan kekurangan stok bahan makanan.

4. Teori Rasio Ketergantungan (Dependency Ratio)

Rasio ketergantungan (Dependency Ratio) adalah perbandingan antara jumlah penduduk berumur 0-11 tahun ditambah dengan jumlah penduduk 65 tahun keatas (secara umum dikategorikan sebagai penduduk usia tidak produktif) dibandingkan dengan jumlah penduduk usia 15-64 tahun (penduduk usia produktif). Rasio ketergantungan dapat dilihat menurut usia yakni Rasio Ketergantungan Muda dan Rasio Ketergantungan Tua.

Analisis Mill untuk mengatasi kemiskinan dengan pengendalian pertumbuhan penduduk golongan kelas pekerja. Mill meyakini bahwa pembatasan penduduk merupakan hal yang penting untuk memperbaiki kondisi kelas pekerja sehingga mereka dapat menikmati hasil kemajuan teknologi, akumulasi modaldan kesejahteraan pendapatan, Mill menyarankan adanya pembatasan kelahiran sebagai lawan dari moral (Jhingan, 2004).

Analisis Hukum Okun dalam mengatasi kemiskinan melalui human capital investment sebagai cara untuk menurunkan tingkat pengangguran, hal ini membuat produktivitas tenaga kerja menjadi tinggi, yang secara langsung dapat meningkatkan daya beli masyarakat karena adanya kenaikan pendapatan per riil tenaga kerja yang merupakan langkah untuk mengatasi kemiskinan (Arsyad, 2010). Analisis Keynes untuk mengatasi kemiskinan adalah melalui permintaan efektif yang menentukan tingkat 
keseimbangan pekerjaan dan pendapatan. Permintaan efektif terdiri dari permintaan konsumsi dan permintaan investasi.

\section{Previous Study and Hypothesis}

Rasidin K. Sitepu dan Bonar M. Sinaga (2005) dengan judul Dampak Investasi Sumberdaya Manusia Terhadap Pertumbuhan Ekonomi Dan Kemiskinan Di Indonesia: Pendekatan Model Computable General Equilibrium menemukan hasil bahwa investasi sumberdaya manusia berdampak langsung pada peningkatan pertumbuhan ekonomi. Investasi kesehatan dan investasi pendidikan sama-sama dapat mengurangi kemiskinan, namun investasi kesehatan memiliki persentase yang lebih besar. Muhammad Arif Widodo (2014) dengan judul Pengaruh rata-rata lama sekolah, pertumbuhan ekonomi dan penyerapan tenaga kerja terhadap persentase penduduk miskin di kabupaten/kota di Provinsi Jawa Timur tahun 2007-2011 menemukan Variabel rata-rata lama sekolah berpengaruh negatif secara signifikan terhadap penyerapan tenaga kerja, variabel penyerapan tenaga kerja berpengaruh positif secara signifikan terhadap persentase penduduk miskin \& variabel pertumbuhan ekonomi berpengaruh positif secara signifikan terhadap variabel penyerapan tenaga kerja. Sedangkan Renta Yustie (2013) menemukan hasil bahwa belanja modal, pertumbuhan ekonomi dan tingkat pengangguran terbuka secara bersama-sama mempunyai pengaruh yang signifikan terhadap tingkat kemiskinan pada masing-masing kabupaten/kota di Provinsi Jawa Timur tahun 2007-2011.

Analisis Pengaruh Pertumbuhan Ekonomi, Pendidikan Dan Kesehatan Terhadap Kemiskinan Kabupaten/Kota Di Provinsi Jawa Tengah Tahun 2005-2008 oleh Ravi Dwi Wijayanto (2010) ditemukan hasil Pertumbuhan ekonomi mempunyai pengaruh yang negatif dan tidak signifikan terhadap kemiskinan di Jawa Tengah.Variabel pendidikan dan kesehatan memiliki pengaruh negatif dan signifikan kemiskinan di Jawa Tengah tahun 2005-2008. Economic Growth and Poverty Reduction: Evidence from Kazakhtan oleh Pradeep Agrawal (2008) menemukan Pertumbuhan ekonomi memiliki hubungan yang negatif dengan kemiskinan, sedangkan ketimpangan memiliki hubungan yang positif

dengan kemiskinan. Ketika terjadi pertumbuhan ekonomi yang diikuti dengan peningkatan jumlah tenaga kerja dan tingginya tingkat upah riil, akan berpengaruh secara signifikan terhadap pengurangan kemiskinan. Dan Minimum Wages and Poverty in a Developing Country: Simulations from Indonesia's Household Survey oleh Kelly Bird dan Chriss Manning (2008) menggunakan metode simulasi didapatkan kesimpulan bahwa kebijakan upah minimum bukan merupakan kebijakan efektif untuk menyerap tenaga kerja dan menurunkan tingkat kemiskinan di Indonesia. 


\section{RESEARCH METHODS}

Data yang digunakan dalam penelitian ini menggunakan data sekunder, data diperoleh dari Badan Pusat Statistik (BPS) Provinsi Jawa Timur dan juga Disnaker Jawa Timur melalui metode dokumenter. Data yang sudah ada disesuaikan selanjutnya diolah dan dianalisis secara kuantitatif.

\section{Kerangka Konseptual}

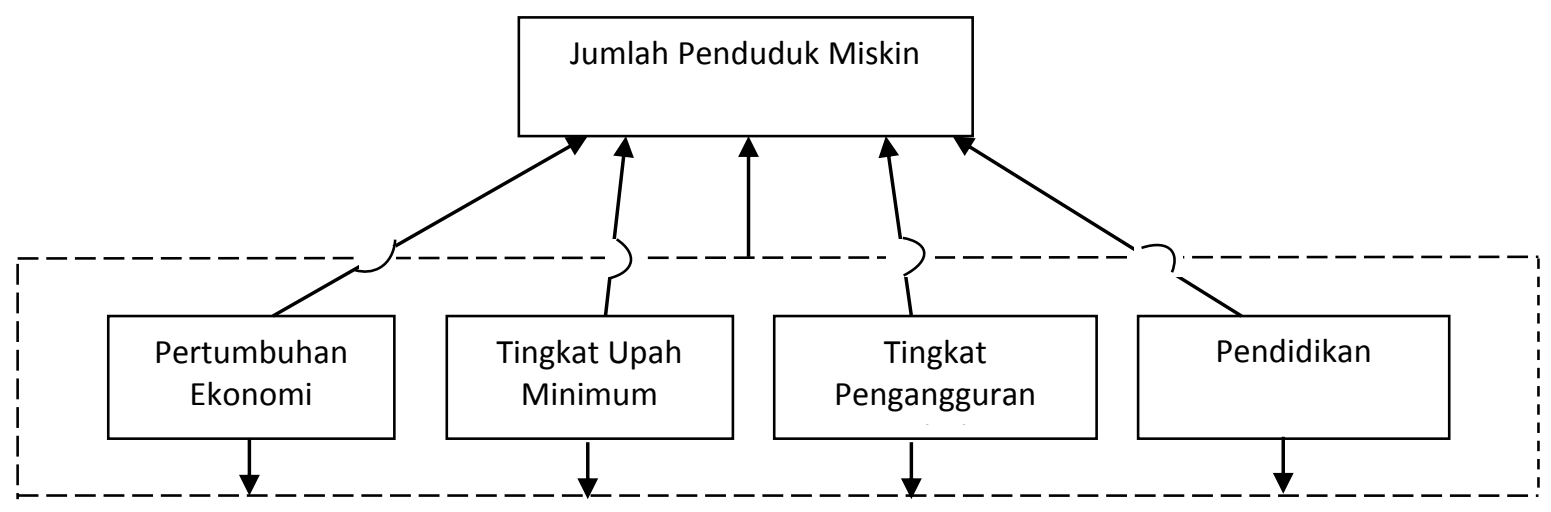

\section{Teknik Analisis}

a. Pooled Least Square

$$
Y_{i t}=\beta o+\beta_{1} X_{1 i t}+\beta_{2} X_{2 i t}+\beta_{3} X_{3 i t}+\ldots .+\beta_{n} X_{\text {nit }}+u_{\text {it }}
$$

b. Fixed Effects Model

$$
Y_{i t}=\alpha_{1}+\alpha_{2} D_{2}+\ldots . .+\alpha_{n} D_{n}+\beta_{2} X_{2 i t}+\ldots+\beta_{n} X_{n i t}+u_{i t}
$$

c. Random Effects Model

$$
Y_{i t}=\beta_{1}+\beta_{2} X_{2 i t}+\ldots+\beta_{n} X_{n i t}+\varepsilon_{i t}+u_{i t}
$$

\section{RESULT AND ANALYSIS}

Hasil penelitian menunjukkan pertumbuhan ekonomi tidak berpengaruh signifikan terhadap jumlah penduduk miskin Kabupaten / Kota Jawa Timur tahun 20082013. Dengan demikian hipotesis penelitian, yang menyatakan pertumbuhan ekonomi berpengaruh signifikan terhadap jumlah penduduk miskin Kabupaten/Kota di Provinsi Jawa Timur tahun 2008-2013 tidak sesuai dengan hasil penelitian. Ini berarti, hipotesis penelitian ditolak. Hasil tersebut tidak sesuai dengan teori dan penelitian terdahulu yang menjadi landasan teori dalam penelitian ini. Yang mana menurut Kuznet dalam Todaro (2006), pertumbuhan dan kemiskinan mempunyai korelasi yang sangat kuat, karena pada tahap awal proses pembangunan kemiskinan cenderung meningkat dan pada saat mendekati tahap akhir pembangunan jumlah orang miskin berangsur-angsur berkurang. 
Hermanto dan Dwi (2008) mengungkapkan pentingnya mempercepat pertumbuhan ekonomi untuk menurunkan penduduk miskin, karena dengan pertumbuhan ekonomi yang cepat maka kemiskinan di suatu daerah dapat ditekan jumlahnya. Yang mana kemiskinan merupakan salah satu indikator keberhasilan pembangunan daerah. Ketidaksignifikannya PDRB dalam mempengaruhi kemiskinan juga dapat dilihat berdasarkan data bahwa peningkatan laju PDRB di Jawa Timur dari tahun 2008 sampai dengan tahun 2013 tidak selalu diiringi dengan penurunan jumlah penduduk miskin di Jawa Timur.

Tabel 1

Hasil Pengujian Regresi Seluruh Data Panel

\begin{tabular}{ccc}
\hline Hubungan antar variabel & $\begin{array}{c}\text { Prob t- } \\
\text { statistik }\end{array}$ & Keterangan \\
\hline Pertumbuhan Ekonomi $\rightarrow$ Jumlah Penduduk Miskin & 0.6137 & Ho diterima \\
\hline Upah Minimum $\rightarrow$ Jumlah Penduduk Miskin & 0.0000 & Ho ditolak \\
\hline Tingkat Pengangguran Terbuka $\rightarrow$ Jumlah Penduduk Miskin & 0.0342 & Ho ditolak \\
\hline Pendidikan $\rightarrow$ Jumlah Penduduk Miskin & 0.0000 & Ho ditolak \\
\hline
\end{tabular}

Sumber: Hasil Perhitungan Eviews

Dari hasil regresi ditemukan bahwa upah minimum memberikan pengaruh yang negatif dan signifikan terhadap tingkat jumlah penduduk miskin di 38 kabupaten/kota di Provinsi Jawa Timur. Hal ini berarti kenaikan upah minimum sebesar 1 rupiah akan menyebabkan penurunan jumlah penduduk miskin sebesar $4.51 \times 10^{-2}$ jiwa. Semakin tinggi upah minimum akan memicu penurunan jumlah penduduk miskin. Hasil ini sesuai dengan tujuan penetapan upah minimum yang disampaikan Kaufman (2000) dan dalam Peraturan Menteri Tenaga Kerja Nomor : Per-01/Men/1999 dan UU Ketenagakerjaan No. 13 tahun 2003, yaitu untuk meningkatkan kesejahteraan pekerja, sehingga terbebas dari kemiskinan. Penetapan upah minimum yang mendekati KHM (Kebutuhan Hidup Minimum) dan diatas garis kemiskinan telah tepat karena mampu menurunkan jumlah penduduk miskin di Jawa Timur. Hasil penelitian menunjukkan bahwa upah minimum berpengaruh negatif terhadap jumlah penduduk miskin sesuai dengan hipotesis penelitian yang diajukan, maka hipotesis penelitian dapat diterima.

Dari hasil regresi yang dihasilkan dalam penelitian ini menunjukan bahwa variabel tingkat pengangguran terbuka menunjukkan tanda negatif dan berpengaruh secara signifikan terhadap jumlah penduduk miskin di Jawa Timur. Dimana kenaikan tingkat pengangguran terbuka sebanyak 1 persen tidak menaikkan kemiskinan tetapi dari hasil penelitian ini malah akan menurunkan kemiskinan sebesar 1569.148 jiwa. Hasil tersebut tidak sesuai dengan teori dan penelitian terdahulu yang menjadi landasan teori dalam penelitian ini. Hasil penelitian yang menunjukan pengaruh negatif pengangguran terhadap kemiskinan juga dapat dilihat berdasarkan data tingkat pengangguran terbuka di Kabupaten/Kota Jawa Timur dari tahun 2008-2013 yang menunjukan angka tingkat 
pengangguran terbuka yang terus meningkat, sedangkan data kemiskinan tahun 2008 2013 malah mengalami penurunan. Selain itu, bahwa tidak semua orang menganggur itu selalu miskin. Karena seperti halnya penduduk yang termasuk dalam kelompok pengangguran terbuka ada beberapa macam penganggur, yaitu mereka yang mencari kerja, mereka yang mempersiapkan usaha, mereka yang tidak mencari pekerjaan karena merasa tidak mungkin mendapatkan pekerjaan dan yang terakhir mereka yang sudah punya pekerjaan tetapi belum mulai bekerja.

Variabel pendidikan yang diproksi dengan besarnya rata-rata lama sekolah menunjukkan tanda negatif dan berpengaruh secara signifikan terhadap jumlah penduduk miskin di Jawa Timur. Peningkatan rata-rata lama sekolah sebagai indikator pendidikan di Jawa Timur sebesar 1 tahun akan menurunkan jumlah penduduk miskin sebesar 38633.31 jiwa. Yang berarti bahwa peningkatan angka rata-rata lama sekolah akan menurunkan jumlah penduduk miskin di jawa Timur. Hasil tersebut sesuai dengan teori dan penelitian terdahulu yang menjadi landasan teori dalam penelitian ini. Menurut Kuznet (dalam Todaro, 2006), pendidikan di banyak negara merupakan cara untuk menyelamatkan diri dari kemiskinan. Dimana digambarkan dengan seorang miskin yang mengharapkan pekerjaaan baik serta penghasilan yang tinggi maka harus mempunyai tingkat pendidikan yang tinggi. Tetapi pendidikan tinggi hanya mampu dicapai oleh orang kaya. Sedangkan orang miskin tidak mempunyai cukup uang untuk membiayai pendidikan hingga ke tingkat yang lebih tinggi seperti sekolah lanjutan dan universitas. Sehingga dapat dikatakan bahwa tingkat pendidikan sangat berpengaruh terhadap terjadinya peningkatan kemiskinan.

\section{CONCLUSION}

Pertumbuhan ekonomi, upah minimum, tingkat pengangguran terbuka dan pendidikan secara bersama-sama mempunyai pengaruh signifikan terhadap jumlah penduduk miskin kabupaten/kota di Provinsi Jawa Timur tahun 2008-2013. Pertumbuhan Ekonomi mempunyai pengaruh negatif dan tidak signifikan mempengaruhi jumlah penduduk miskin. Hal ini dikarenakan bahwa peningkatan PDRB yang terjadi di Jawa Timur tidak selalu diikuti oleh penurunan jumlah penduduk miskin di Jawa Timur. Upah Minimum mempunyai pengaruh negatif dan signifikan mempengaruhi jumlah penduduk miskin. Pengaruh signifikan menunjukkan bahwa upah minimum mampu memberikan respon pada penurunan jumlah penduduk miskin. Penyebab upah minimum mampu menurunkan jumlah penduduk miskin karena meningkatkan pendapatan masyarakat miskin. Tingkat Pengangguran Terbuka mempunyai pengaruh negatif dan signifikan mempengaruhi jumlah penduduk miskin. Pengaruh signifikan menunjukkan bahwa tingkat pengangguran terbuka mampu memberikan respon pada penurunan jumlah penduduk miskin. Penyebab tingkat penagngguran terbuka mampu 
menurunkan jumlah penduduk miskin karena berkurangnya jumlah penganggur dan meningkatkan pendapatan masyarakat miskin. Pendidikan (rata-rata lama sekolah) mempunyai pengaruh negatif dan signifikan mempengaruhi kemiskinan. Pengaruh signifikan menunjukkan bahwa pendidikan mampu memberikan respon pada penurunan jumlah penduduk miskin. Penyebab pendidikan mampu menurunkan jumlah penduduk miskin karena dengan pendidikan yang tinggi, masyarakat semakin memiliki keterampilan dan mampu bersaing dalam dunia kerja.

Diharapkan bahwa pemerintah provinsi Jawa Timur seharusnya meningkatkan total produksi barang dan jasa yang dihasilkan di seluruh Kabupaten/ Kota di Jawa Timur, mempertimbangkan besaran upah minimum provinsi sehingga dapat menekan jumlah penduduk miskin di seluruh Kabupaten/ Kota di Jawa Timur dan lebih menggerakkan sektor formal. Pengangguran dalam penelitian ini menggunakan data pengangguran terbuka, yang mana di dalamnya terdapat golongan masyarakat yang sedang dalam tahap menyiapkan usaha atau mendapat pekerjaan tetapi belum mulai bekerja yang dimasukkan dalam golongan pengangguran. Sehingga pentingnya peningkatan sektor informal untuk menekan jumlah penduduk miskin di Kabupaten/ Kota di Jawa Timur. Menurunkan tingkat pengangguran terbuka kabupaten/kota di Provinsi Jawa Timur dengan cara:

1. Memberikan pendidikan dan latihan kerja

2. Perluasan kesempatan kerja di dalam negeri dan ke luar negeri

3. Percepatan industrialisasi di sektor perekonomian dan di daerah pedesaan, supaya menyerap banyak tenaga kerja.

\section{REFERENCES}

Arsyad, Lincoln, 2010, Ekonomi Pembangunan. Edisi 5, Universitas Gadjah Mada. Yogyakarta: Unit Penerbit dan Percetakan STIM YKPN.

Agrawal, Pradeep. 2008. Economic Growth and Poverty Reduction: Evidence

From Kazakhstan, Asian Development Review, vol. 24, no.2, pp. 90-115. Available: http://www.adb.org

BPS, 2012a, Analisis Indikator Makro Sosial dan Ekonomi Kabupaten /Kota Provinsi Jawa Timur 2008-2013, Badan Pusat Statistik Jawa Timur.

------------,2012b, Provinsi Jawa Timur, Badan Pusat Statistik Jawa Timur.

-------------,2012c, Provinsi Jawa Timur dan Pemerintah Provinsi Jawa Timur, Badan Pusat Statistik Jawa Timur.

,2012d, Produk Domestik Regional Bruto Provinsi Jawa Timur 20082012, Badan Pusat Statistik Jawa Timur. 
Jurnal Ekonomi dan Bisnis Airlangga, Vol. 28, No.2, June - November 2018

,2013a, Jawa Timur Dalam Angka, Badan Pusat Statistik Jawa Timur.

2013b, Statistik Upah, Badan Pusat Statistik Jawa Timur.

Hermanto Siregar dan Dwi Wahyuniarti, 2008, Dampak Pertumbuhan Ekonomi Terhadap Penurunan Jumlah Penduduk Miskin.

http://pse.litbang.deptan.go.id/ind/pdffiles/PROS_2008_MAK3.pdf. Diakses tanggal 29 Oktober 2009.

Husna, Auliya dan Hermawan, Abdul Wachid, 2010, Evaluasi Pelaksanaan Program Penanggulangan Kemiskinan Jalin Kesra (Jalan Lain Menuju Kesejahteraan Rakyat) Sebagai Upaya Mendukung Pencapaian Target MDG's (Millenium Development Goals) Di Provinsi Jawa Timur (Studi Pada Crisis Center Pendampingan Provinsi Jawa Timur)

Jhingan, M.L., 2004, Ekonomi Pembangunan dan Perencanaan. Jakarta: Rajawali Press.

Michael, P Todaro dan Stephen C. Smith. Pembangunan Ekonomi. 1998. Jakarta: Erlangga.

Rasidin K. Sitepu dan Bonar M. Sinaga, 2004. Dampak Investasi Sumber Daya ManusiaTerhadap Pertumbuhan Ekonomi Dan Kemiskinan Di Indonesia: Pendekatan Model Computable General Equilibrium. http://ejournal.unud.ac.id/?module=detailpenelitian\&idf=7\&idj=48\&idv=181 \&idi $=48 \& i d r=191$. Diakses tanggal 29 Oktober 2009.

Sonny Sumarsono, 2003, Ekonomi Manajemen Sumber Daya Manusia Dan Ketenagakerjaan. Penerbit Graha Ilmu, Jember.

Todaro, Michael. 2006. Pembangunan Ekonomi, Edisi Ke-9, PT Gelora Akasara Pratama, Jakarta.

Wongdesmiwati, 2009. Pertumbuhan Ekonomi Dan Pengentasan Kemiskinan Di Indonesia: Analisis Ekonometrika. http://wongdesmiwati.files.wordpress.com/2009/10/pertumbuhanekonomi dan pengentasan- kemiskinan-di-indonesia-_analisisekonometri_.pdf. Diakses tanggal 7 Desember 2009.

Yustie Renta, 2013, “Pengaruh Belanja Modal, Pertumbuhan Ekonomi, Tingkat Pengangguran Terbuka Terhadap Tingkat Kemiskinan Kabupaten/Kota di Provinsi Jawa Timur Tahun 2007-2011", Tesis, Universitas Airlangga, Surabaya.

Widodo, M.A, 2014, “Pengaruh Rata-Rata Lama Sekolah Dan Pertumbuhan Ekonomi Serta Penyerapan Tenaga Kerja Terhadap Persentase Penduduk Miskin Di 
Kabupaten dan Kota Di Jawa Timur Tahun 2007-2011", Tesis, Universitas Airlangga, Surabaya. 